УДК 616.31:602.9:616-008.9-048.38:616-008.852

DOI 10.11603/2311-9624.2020.3.11566

\author{
(С) В. Бамбуляк, Н. Б. Кузняк, Р. Р. Дмитренко, С. В. Ткачик, В. А. Гончаренко \\ Буковинський державний медичний університет, м. Чернівці \\ e-mail: bambuljak.andrij@bsmu.edu.ua

\section{Фенотипова характеристика мультипотентних мезенхімальних стромальних клітин жирової тканини та оцінка ступеня іiі мінералізації IN VITRO}

\section{ІНФОРМАЦІЯ}

Надійшла до редакціі//Received: 09.09.2020 p.

Ключові слова: мезенхімальні стромальні клітини; жирова тканина; плазма, збагачена тромбоцитами; експресія поверхневих антигенів.
АНОТАЦІЯ

Резюме. У лікарській практиці фахівці досить часто стикаються 3 травмами різної етіології. Актуальною є мета в короткий термін, мінімальними затратами та впливом на організм реконструювати ушкоджену тканину. Використання стовбурових клітин у стоматологічній практиці стало можливим завдяки феноменальним відкриттям в біології та біотехнології, які стосуються здатності стовбурових клітин після введення їх в організм реципієнта надходити в місця ушкоджень тканин і відновлювати їх клітинну структуру. Мета дослідження - визначити біосумісність мезенхімальних стромальних клітин жирової тканини (ММСК-ЖТ) з остеопластичними матеріалами.

Матеріали і методи. Дослідження проводили на базі Буковинського державного медичного університету. Зразки жирової тканини були отримані з ділянки шиї 60 експериментальних тварин (білі щури лінії Вістар). Мультипотентні мезенхімальні клітини жирової тканини (ММСК-ЖТ) отримували шляхом подрібнення жирової тканини щурів. Фенотипування ММСК-ЖТ за маркерами СД 44, СД 45, СД 73, СД 90, СД 117, Sca-1 проводили 3 використанням моноклоніальних антитіл до мембранних антигенів миші, кон’югованих з флуорохромами. Оцінювали проліферації фібробластів за допомогою тесту Alamar Blue (AB, Serotec) на 3; 7 та 10 доби після початку експерименту.

Результати досліджень та їх обговорення. Культивовані ММСКЖТ експериментальних щурів 2-го пасажу експресують характерні для ММСК маркери ММСК-ЖТ, здатні до диференціації в остеогенному напрямку, при превалюванні даного процесу в тканинних зразках, що містили плазму, збагачену тромбоцитами, та колопан. Під час остеогенної диференціації відбувалась морфологічна зміна клітин із синтезом і мінералізацією позаклітинного матриксу та утворенням клітинних агрегатів. Аналіз ступеня мінераліації позаклітинного матриксу виявив, що досліджувані зразки з вмістом ММСК-ЖТ мають остеогенний потенціал, який був більш виражений у зразках «ММСК-ЖТ + плазма, збагачена тромбоцитами» та «ММСК-ЖТ + плазма, збагачена тромбоцитами + колапан».

Висновки. Тканинні еквіваленти кісткової тканини на основі мультипотентних мезенхіальних стромальних клітин із жирової тканини можуть бути кандидатами для застосування у регенеративній медицині, а дослідження їх на експериментальних тваринах нададуть можливість для розширення уявлення про характе- 
ристику ММСК-ЖТ з метою оптимізації їх подальшого клінічного застосування і реалізації нових підходів у різних напрямках стоматології.

Вступ. У лікарській практиці фахівці досить часто стикаються з травмами різної етіології. Актуальною є мета в короткий термін, з мінімальними затратами та впливом на організм реконструювати ушкоджену тканину [1]. Використання стовбурових клітин [2] у стоматологічній практиці стало можливим завдяки феноменальним відкриттям в біології та біотехнології, які стосуються здатності стовбурових клітин після введення їх в організм реципієнта надходити в місця ушкоджень тканин i відновлювати їх клітинну структуру [3, 4].

Встановлена здатність стовбурових клітин диференціюватись практично в усі спеціалізовані клітини організму і виконувати специфічні біологічні функції [5]. Дослідники працюють в основному 3 ембріональними та мезенхімальними стовбуровими клітинами [6]. Мезенхімальні стовбурові клітини виявлені в стромі кісткового мозку, є одним із різновидів стовбурових клітин дорослого організму. Зокрема, вони були виділені зі скелетних м'язів, жирової тканини, легень, фетальної печінки, кордової крові [7]. Їх відносять до мультипотентних клітин, тобто здатних диференціюватися у клітини сполучної тканини, включаючи кісткову, жирову, хрящову і м'язову тканини, тому вони $€$ оптимальними для клітинно-регенеративної терапії ушкоджень вищеназваних тканин [8]. Оптимальним джерелом отримання мультипотентних стовбурових клітин є жирова тканина. Насамперед, це пояснюється доступністю методики отримання клітин, низької інвазивності для організму, можливістю в достатній кількості та в потрібний час отримати клітинний матеріал [9]. Мультипотентні мезенхіальні стромальні клітини 3 жирової тканини здатні до диференціації в адипогенному, остеогенному, хондрогенному, ендотеліальному, міогенному, гепатогенному, епітеліальному та нейрогенному напрямках [10-12].

Оскільки загоєння кісткової тканин відбувається за допомогою заміщення дефекту сполучною тканиною, нашим завданням була трансплантація мультипотентних стовбурових клітин, які в подальшому будуть диференціюватись у власне кісткову тканину [13].

Метою дослідження було визначити біосумісність мезенхімальних стромальних клітин жирової тканини (ММСК-ЖТ) з остеопластичними матеріалами.

Матеріали і методи. Дослідження проводилося на базі Буковинського державного медичного університету. Зразки жирової тканини були отримані з ділянки шиї 60 експериментальних тварин (білі щури лініі Вістар) [14]. Для токсикологічного експерименту, який дозволяє встановити прямий вплив факторів при контакті імплантаційного матеріалу на клітинному рівні, відібрано 4 зразки: № 1 - ММСК-ЖТ, що пройшли остеогенне диференціювання; № 2 - ММСК-ЖТ 3 остеогенним диференціюванням із додаванням плазми крові, збагаченої тромбоцитами; № 3 - колапан 3 нанесеною тканинною культурою клітин ММСК-ЖТ, що пройшла остеогенне диференціювання; № 4 - колапан 3 нанесеною тканинною культурою клітин ММСК-ЖТ, що пройшла остеогенне диференціювання, та плазми крові, збагаченої тромбоцитами. Мультипотентні мезенхімальні клітини жирової тканини (ММСК-ЖТ) отримували шляхом подрібнення жирової тканини щурів у 0,1 \% колагенази 1А [15]. Фенотипування ММСК-ЖТ за маркерами СД 44, СД 45, СД 73, СД 90, СД 117, Sса-1 проводили 3 використанням моноклоніальних антитіл до мембранних антигенів миші, кон'югованих з флуорохромами [16]. Оцінювання проліферації фібробластів проводили за допомогою тесту Alamar Blue (AB, Serotec) на 3; 7 та 10 доби після початку експерименту [17]. Статистичну обробку результатів досліджень здійснювали за допомогою загальноприйнятих методів варіаційної статистики.

Результати досліджень та їх обговорення. Фенотиповий аналіз ММСК-ЖТ виявив профіль експресії поверхневих маркерів, які є характерними для стромальних клітин із мультипотентними властивостями (рис.).

При дослідженні зразків 0-пасажу (3-4 доби спостереження) визначали експресію поверхневих антигенів CD 73 до $(73,5 \pm 6,68) \%$ клітин, які впливають на популяції Т- і В-лімфоцитів та CD 45 - до $(60,5 \pm 5,50) \%$ клітин, які відповідають за присутність гемопоетичних клітин. При цьому при вивченні зразків 0-пасажу спостерігали високу кількість CD 117-хелперів

ISSN 2311-9624. Клінічна стоматологія. 2020. № 3 


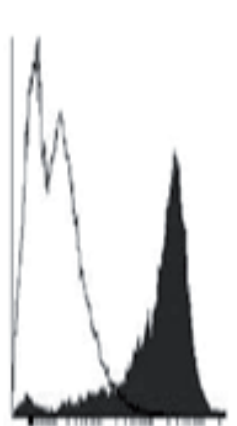

COA P.P.A

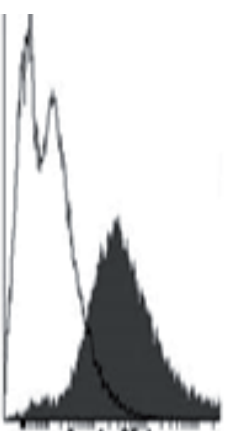

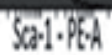
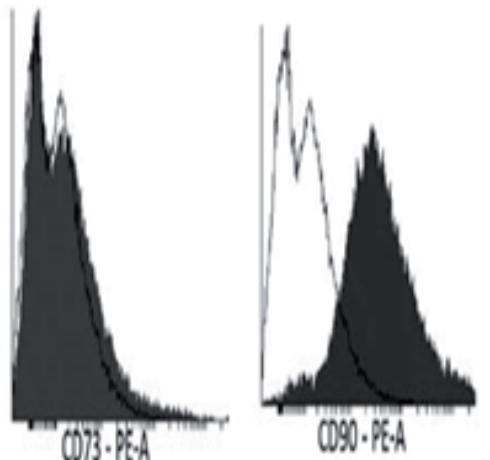

$\operatorname{COSOPOPSA}$
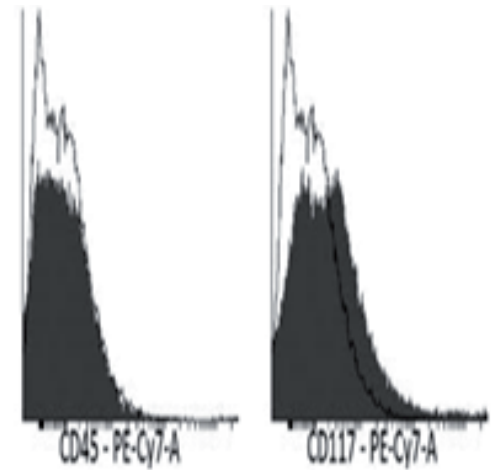

Puc. Гістограма експресії поверхневих маркерів CD 44, Sca-1, CD 73, CD 90, CD 45, CD 117 в культурах клітин жирової тканини щурів. Прозора гістограма - контрольні зразки без внесення антитіл, темна - рівень флюоресценції у зразку з додаванням моноклональних антитіл.

$(95,0 \pm 8,64) \%$, що ініціюють фактор росту стовбурових клітин.

Фенотиповий аналіз маркерів ММСК-ЖТ 2-го пасажу продемонстрував експресію антигенів Sca-1 - до $(89,3 \pm 8,12) \%$, CD 90 - до $(93,7 \pm 8,52) \%$, CD 44 - до $(97,8 \pm 8,98) \%$, що у 2,7 ; 9,4 та в 4,0 рази, відповідно, перевищувало кількісний склад поверхневих антигенів 0-па- сажу ММСК-ЖТ, p<0,01. При цьому визначено зменшення панлейкоцитарного маркера CD 45 до $(1,60 \pm 0,15) \%$ клітин, CD 117 - до $(4,7 \pm 0,43)$ \%, що свідчило про відсутність кровотворних клітин у цих зразках (табл. 1). Отже, такий же імунофенотиповий профіль дослідила низка авторів для ММСК, виділених із жирової тканини.

таблиия 1. Фенотиповий аналіз поверхневих маркерів ММСК-ЖТ у щурів лінії Вістар (Mェm, \%)

\begin{tabular}{|l|c|c|c|c|c|c|}
\hline \multicolumn{1}{|c|}{ Зразок } & Sca-1(\%) & CD 73 (\%) & CD 117 (\%) & CD 44 (\%) & CD 45 (\%) & CD 90 (\%) \\
\hline $\begin{array}{l}\text { 0-пасаж } \\
\text { ММСК-ЖТ }\end{array}$ & $32,9 \pm 2,99$ & $73,5 \pm 6,68$ & $95,0 \pm 8,64$ & $23,8 \pm 2,53$ & $60,5 \pm 5,50$ & $10,0 \pm 0,91$ \\
\hline $\begin{array}{l}\text { 2-пасаж } \\
\text { ММСК-ЖТ }\end{array}$ & $89,3 \pm 8,12^{\circ}$ & $14,5 \pm 1,32^{\circ}$ & $4,7 \pm 0,43^{\circ}$ & $97,8 \pm 8,98^{\circ}$ & $1,60 \pm 0,15^{\circ}$ & $93,7 \pm 8,52^{\circ}$ \\
\hline
\end{tabular}

Примітка. ำ<0,01 - достовірна різниця значень стосовно даних 0-пасажу ММСК-ЖТ.

Однією з головних характеристик ММСК-ЖТ є здатність до диференціації в різні типи клітин сполучної тканини. У нашому дослідженні для з'ясування біологічних властивостей
ММСК-ЖТ визначали потенціал цих клітин до спрямованого диференціювання в остеогенному напрямку (табл. 2).

таблищя 2. Ступінь мінералізації культур ММСК-ЖТ колометричним методом

\begin{tabular}{|l|c|c|c|}
\hline \multirow{2}{*}{ 3разок } & \multicolumn{3}{|c|}{ Термін спостереження } \\
\cline { 2 - 4 } & 5 доба & 7 доба & 10 доба \\
\hline № 1 (ММСК-ЖТ) & $1,38 \pm 0,27$ & $2,56 \pm 0,51$ & $2,95 \pm 0,59$ \\
\hline № 2 (ММСК-ЖТ + 3ТП) & $3,15 \pm 0,43^{\circ}$ & $3,92 \pm 0,74$ & $4,00 \pm 0,80$ \\
\hline № 3 (ММСК-ЖТ + колапан) & $2,64 \pm 0,32^{\circ}$ & $2,76 \pm 0,55$ & $3,22 \pm 0,65$ \\
\hline № 4 (ММСК-ЖТ + 3ТП + колапан) & $3,86 \pm 0,56^{\circ}$ & $4,85 \pm 0,97^{\circ}$ & $5,07 \pm 1,01^{\circ}$ \\
\hline
\end{tabular}

Примітка. ${ }^{\circ} \rho<0,05 ;{ }^{\circ} \rho<0,01$ - достовірна різниця значень стосовно даних ММСК-ЖТ.

Перші ознаки впливу остеоіндукції у зразках, що містили ММСК-ЖТ, з'явились на 7 добу культивування, незалежно від їх складу. При цьому досліджувані зразки набували фенотип у кісткової тканини, що характеризувалось утворенням культур із формуванням клітинних агрегатів, синтезом щільного позаклітинного матриксу з явищами кальцифікації. 
При цьому встановлено, що на 5 добу культивування найменша оптична щільність була у зразках № 1 та № 3 - $(1,38 \pm 0,27)$ ум. од. та $(2,64 \pm 0,32)$ ум. од. відповідно, $\mathrm{p}<0,01$. Водночас, оптична щільність зразка № 3 була у 2,3 раза та зразка № 4 - у 2,8 раза більшою, ніж у культурі ММСК-ЖТ (зразок № 1) $\mathrm{p}<0,01$.

На 7 добу спостережень реєстрували збільшення оптичної щільності усіх досліджуваних тканинних культур. Звертало увагу, що на 7 добу культивування значення досліджуваного параметра були однаковими у зразках № 1 та № 3 і коливались від $(2,56 \pm 0,51)$ ум. од. до $(2,86 \pm 0,55)$ ум. од., р>0,05. Разом 3 тим, оптична щільність тканинної культури, що містила ММСК-ЖТ + ЗТП, була у 1,5 раза, $\mathrm{p}>0,05$ та зі складом ММСК-ЖТ + ЗТП + колапан у 1,9 раза вище, $p<0,05$, ніж у зразку ММСК-ЖТ.
На 10 добу спостережень, оптична щільність зразка № 1 становила $(2,95 \pm 0,59)$ ум. од. та була мінімальною. Значення досліджуваного параметра в тканинних культурах «ММСКЖТ + ЗТП» та «ММСК-ЖТ + колапан» хоча і були у 1,4 та 1,1 раза відповідно вище, однак не відрізнялись статистичною значущістю від даних оптичної щільності зразка № $1, \mathrm{p}>0,05$. При цьому на 10 добу культивування оптична щільність зразка № $4-(5,07 \pm 1,01)$ ум. од. була вірогідно вище, $\mathrm{p}<0,05$ даних досліджуваного параметра у зразку № 1.

Характер впливу досліджуваних зразків, що містили ММСК-ЖТ, підтверджувався результатами, отриманими 3 використанням Alamar Blue-тесту при визначенні метаболічної активності ММСК-ЖТ у різних зразках (табл. 3).

таблиця 3. Рівень відновлення Alamar Blue клітинами у зразках, що містили ММСК-ЖТ у різні терміни спостереження

\begin{tabular}{|l|c|c|c|c|}
\hline \multirow{2}{*}{$\begin{array}{c}\text { Термін } \\
\text { дослідження }\end{array}$} & $\begin{array}{c}\text { ММск-ЖТ } \\
\text { (контроль) } \\
\text { зразок № 1 }\end{array}$ & $\begin{array}{c}\text { ММСК-ЖТ + 3ТП } \\
\text { зразок № 2 }\end{array}$ & $\begin{array}{c}\text { ММСК-ЖТ + } \\
\text { колапан } \\
\text { зразок № 3 }\end{array}$ & $\begin{array}{c}\text { ММСК-ЖТ + 3ТП + } \\
\text { колапан } \\
\text { зразок № 4 }\end{array}$ \\
\hline 5 доба & $9,224 \pm 1623$ & $8,324 \pm 1,442$ & $7,126 \pm 1,325$ & $8624 \pm 1503$ \\
\hline 7 доба & $12449 \pm 1638$ & $9549 \pm 1457$ & $7351 \pm 1340^{\circ}$ & $10849 \pm 1518$ \\
\hline 10 доба & $19685 \pm 1653^{*}$ & $12785 \pm 1472^{\circ}$ & $10587 \pm 1355^{\circ}$ & $18085 \pm 1533^{*}$ \\
\hline
\end{tabular}

Примітки: 1) ${ }^{\circ} \rho<0,05 ;{ }^{\circ} \rho<0,01$ - достовірна різниця значень стосовно даних зразка № 1 ;

2) ${ }^{*} \mathrm{p}_{1}<0,01 ; * \mathrm{p}_{1}<0,05$ - достовірна різниця значень стосовно даних на 5 добу культивування.

У результаті проведених досліджень встановлено, що на 5 добу максимальне значення відновлення Alamar Blue (AB) досліджувалось у контрольному зразку, що містив ММСК-ЖТ при даних флуоресценції $(9,224 \pm 1,623)$ УОФ. При цьому мінімальні дані показника флуоресценції на 5 добу культивування визначали у зразку № 3, що містив ММСК-ЖТ + колапан $(7,126 \pm 1,325)$ УОФ, p>0,05. У зразках № 2 (ММСКЖТ + ЗТП) та № 4 (ММСК-ЖТ + ЗТП + колапан) показник флуоресценції був на 9,76 та 6,50 \% нижче стосовно даних зразка № 1, p>0,05.

На 7 добу культивування визначали збільшення значень відновлення АВ в усіх досліджуваних зразках. Водночас, дані показника флуоресценції у контрольному зразку № 1 були максимальні й перевищували значення: у зразку № 2 - на 23,30 \%, у зразку № 3 - на 40,96 \% та у зразку № 4 - на 12,86 \%, p>0,05.

На 10 добу досліджень відновлення Alamar Blue було максимальним в усіх зразках, при найвищому значенні в контрольному зразку
№ 1 - (19685£1653) УОФ. При цьому значення показника флуоресценції було нижче даних у контролі: у зразку № 2 - на 35,05 \%, у зразку № 3 - на 46,22 \%, p<0,01 та у зразку № 4 - на $3,05 \%, \mathrm{p}>0,05$.

Звертало увагу, що найбільше відновлення Alamar Blue на 10 добу культивування визначалось у зразках № 1, що містили ММСК-ЖТ та зразках № 4 (ММСК-ЖТ + ЗТП + колапан), яке було у 2,13 та 2,09 раза, $\mathrm{p}_{1}<0,01$ більше стосовно відповідних значень на 5 добу культивування. Дещо меншим був процес відновлення $\mathrm{AB}$ на 10 добу культивування у зразках № 2 та у зразках № 3: у 1,5 раза, $\mathrm{p}_{1}<0,05, \mathrm{p}_{1}>0,05$ відповідно.

Отже, необхідно зазначити, що зразок № $4 €$ більш ефективним носієм ММСК-ЖТ за рахунок включення плазми крові, збагаченої тромбоцитами, і колапану та наявності у складі останнього колагену широкопористої структури, що підкреслює процес проліферації клітин усередині носія. 
Таким чином, культивовані ММСК-ЖТ тканин експериментальних щурів 2-го пасажу експресують характерні для ММСК маркери ММСК-ЖТ, здатні до диференціації в остеогенному напрямку, при превалюванні даного процесу в тканинних зразках, що містили плазму, збагачену тромбоцитами, та колапан. Під час остеогенної диференціації відбувалась морфологічна зміна клітин із синтезом і мінералізацією позаклітинного матриксу та утворенням клітинних агрегатів. Аналіз ступеня мінераліації позаклітинного матриксу виявив, що досліджувані зразки з умістом ММСК-
ЖТ мають остеогенний потенціал, який був більш виражений у зразках «ММСК-ЖТ + ЗТП» та «ММСК-ЖТ + ЗТП + колапан».

Висновки. Тканинні еквіваленти кісткової тканини на основі ММСК-ЖТ можуть бути кандидатами для застосування у регенеративній медицині, а дослідження їх на експериментальних тваринах дадуть можливість розширити уявлення про характеристики ММСК-ЖТ з метою оптимізації їх подальшого клінічного застосування і реалізації нових підходів у різних напрямках стоматології.

\section{(ㄱ) А. В. Бамбуляк, Н. В. Кузняк, Р. Р. Дмитренко, С. В. Ткачик, В. А. Гончаренко} Буковинский государственный медицинский университет, г. Черновцы

\section{Фенотипическая характеристика мультипотентных мезенхимальных стромальных клеток жировой ткани и оценка степени ее минерализации IN VITRO}

Резюме. Во врачебной практике специалисты довольно часто сталкиваются с травмами различной этиологии. Актуальна цель в короткий срок с минимальными затратами и влиянием на организм реконструировать поврежденную ткань. Использование стволовых клеток в стоматологической практике стало возможным благодаря феноменальным открытием в биологии и биотехнологии, касающиеся способности стволовых клеток после введения их в организм реципиента поступать в места повреждений тканей и восстанавливать их клеточную структуру.

Цель исследования - определить биосовместимость мезенхимальных стромальных клеток жировой ткани (ММСК-ЖТ) с остеопластическими материалами.

Материалы и методы. Исследование проводилось на базе Буковинского государственного медицинского университета. Образцы жировой ткани были получены из области шеи 60 экспериментальных животных (белые крысы линии Вистар). Мультипотентные мезенхимальные клетки жировой ткани (ММСК-ЖТ) получали путем измельчения жировой ткани крыс. Фенотипирования ММСК-ЖТ по маркерам СД 44, СД 45, СД 73, СД 90, СД 117, Sса-1 проводили с использованием моноклониальних антител к мембранным антигенам мыши, конъюгированных с флуорохромами. Оценивания пролиферации фибробластов проводили с помощью теста Alamar Blue на 3; 7 и 10 сутки после начала эксперимента. Результаты исследований и их обсуждение. Культивируемые ММСК-ЖТ экспериментальных крыс второго пассажа экспрессируют характерные для ММСК маркеры ММСК-ЖТ, способны к дифференциации в остеогенном направлении, при превалировании данного процесса в тканевых образцах, содержащих плазму, обогащенную тромбоцитами, и колапан. Во время остеогенной дифференциации происходило морфологическое изменение клеток с синтезом и минерализацией внеклеточного матрикса и образованием клеточных агрегатов. Анализ степени минералиации внеклеточного матрикса обнаружил, что исследуемые образцы с содержанием ММСК-ЖТ имеют остеогенный потенциал, который был более выражен в образцах «ММСК-ЖТ + обогащенная тромбоцитами плазма» и «ММСКЖТ + обогащенная тромбоцитами плазма + коллапан».

Выводы. Тканевые эквиваленты костной ткани на основе мультипотентных мезенхимальных стромальных клеток из жировой ткани могут быть кандидатами для применения в регенеративной медицине, а исследования их применения на экспериментальных животных предоставят возможность для расширения представления о характеристиках ММСК-ЖТ с целью оптимизации их дальнейшего клинического применения и реализации новых подходов в разных направлениях стоматологии.

Ключевые слова: мезенхимальные стромальные клетки; жировая ткань; обогащенная тромбоцитами плазма; экспрессия поверхностных антигенов. 
(C)A. V. Bambuliak, N. B. Kuznjak, R. R. Dmitrenko, S. V. Tkachik, V. A. Honcharenko Bukovynian State Medical University, Chernivtsi

\section{Phenotypic characteristics of multipotent mesenchymal stromal cells of adipose tissue and evaluation of the degree of its mineralization IN VITRO}

Summary. In medical practice, specialists quite often encounter injuries of various etiologies. The current goal is to make reconstruction of the damaged tissue in a short term, with minimal cost and effect on the body. The use of stem cells in dental practice has become possible due to the phenomenal discovery in biology and biotechnology regarding the ability of stem cells, after injecting them into the recipient's body, to enter the places of damaged tissues and restore their cellular structure.

The aim of the study - to determine the biocompatibility of mesenchymal stromal cells of adipose tissue with osteoplastic materials

Materials and Methods. The study was conducted at the Bukovynian State Medical University, Chernivtsi, Ukraine. Adipose tissue samples were obtained from the neck of 60 experimental animals (white Wistar rats). Multipotent mesenchymal adipose tissue cells (MMSC - AT) were obtained by grinding adipose tissue of rats. Phenotyping of MMSC - AT by markers SD 44, SD 45, SD 73, SD 90, SD 117, Sca-1 was performed using monoclonal antibodies to mouse membrane antigens conjugated to fluorochromes. Evaluation of fibroblast proliferation was performed using the Alamar Blue test at 3, 7 and 10 days after the start of the experiment.

Results and Discussion. Cultured MMSC - AT of experimental rats of the 2nd passage express MMSC markers characteristic of MMSC - AT capable of differentiation in the osteogenic direction, with the predominance of this process in tissue samples containing platelet-enriched plasma and Kolapan. During osteogenic differentiation, morphological changes of cells took place, with synthesis and mineralization of the extracellular matrix and formation of cell aggregates. Analysis of the degree of extracellular matrix mineralization revealed that the studied samples containing MMSC - AT have osteogenic potential, which was more pronounced in the samples "MMSC - AT + platelet-enriched plasma" and "MMSC - AT + platelet-enriched plasma + Kolapan ".

Conclusions. Therefore, tissue equivalents of bone tissue based on multipotent mesenchymal stromal cells from adipose tissue can be candidates for use in regenerative medicine, and studies of their use in experimental animals will provide an opportunity to expand understanding of the characteristics of MMSC - AT to optimize their further clinical application and implementation new approaches in different areas of dentistry.

Key words: mesenchymal stromal cells; adipose tissue; platelet-rich plasma; expression of surface antigens.

\section{СПИСОК ЛІТЕРАТУРИ}

1. Multilineage potential of adult human mesenchymal stem cells / M. F. Pittenger, A. M. Mackay, S. C. Beck [et al.] // Science. - 2015. - Vol. 284. - P. 143-147.

2. Жулкевич I. В. Медико-економічні підходи до трансплантації гемопоетичних стовбурових клітин / І. В. Жулкевич, Г. І. Климнюк // Онкология. 2005. - T. 7, № 4. - C. 357-360.

3. Gimble J. Adipose-derived adult stem cells: isolation, characterization, and differentiation potential / J. Gimble, F. Guilak // Cytotherapy. - 2013. - Vol. 5. P. 362-369.

4. Isolation and culture of inner cell mass cells from human blastocysts / A. Bongso, C. Y. Fong, S. C. Ng, S. Ratnam // Hum. Reprod. - 2014. - Vol. 9. - P. 2110-2117. 5. Embryonic stem cell lines derived from human blastocysts / J. A. Thomson, J. Itskovitz-Eldor, S. S. Shapiro [et al.] // Science. - 2014. - Vol. 282. - P. 1145-1147.

6. Yamanaka S. Pluripotency and nuclear reprogramming / S. Yamanaka // Philos. Trans. R. Soc. Lond. B. Biol. Sci. - 2008. - Vol. 363 (1500). - P. 2079-2087. 7. Hillmann G. Continuous photometric measurement of prostate acid phosphatase activity / G. Hillmann // Z. Klin. Chem. Klin. Biochem. - 1971. - Vol. 9 (3). - P. 273-274.
8. Relationship of plasma tartrate-resistant acid phosphatase to the bone isoenzyme of serum alkaline phosphatase in hyperparathyroidism / J. J. Stepan, E. Silinkova-Malkova, T. Havrenek [et al.] // Clin. Chim. Acta. - 2013. - Vol. 133 (2). - P. 189-200.

9. Горячковский А. М. Клиническая биохимия в лабораторной диагностике. - 3-е изд. / А. М. Горячковский. - Одесса : Экология, 2015. - 616 с.

10. Левицкий А. П. Экспериментальные методы исследования стимуляторов остеогенеза : метод. рекоменд. / А. П. Левицкий, О. А. Макаренко, О. В. Деньга. - К. : ГФЦ МЗУ, 2011. - 50 с.

11. Левицький А. П. Ферментативний метод оцінки стану кісткової тканини / А. П. Левицький, О. А. Макаренко, I. В. Ходаков // Одеський медичний журнал. - 2013. - № 3. - С. 17-21.

12. Жулкевич I. В. Гематологічні аспекти остеопорозу / І. В. Жулкевич, Н. І. Корильчук // Лікарська справа. - 1999. - № 2. - С. 12-17.

13. Cartilage-like gene expression in differentiated human stem cell spheroids: a comparison of bone marrow-derived and adipose tissue-derived stromal cells / A. Winter, S. Breit, D. Parsch [et al.] // Arthritis 
Rheum. - 2014. - Vol. 48. - P. 418-429.

14. Novel maxillary reconstruction with ectopic bone formation by GMP adipose stem cells / K. Mesimäki, B. Lindroos, J. Törnwall [et al.] // Int. J. Oral Maxillofac. Surg. - 2009. - Vol. 38. - P. 201-209.

15. Marrow stromal cells as a source of progenitor cells for nonhematopoietic tissues in transgenic mice with a phenotype of osteogenesis imperfecta / R. F. Pereira, M. D. O'Hara, A. V. Laptev [et al.] // Proc. Natl. Acad. Sci. U.S.A. - 2011. - Vol. 95. - P. 1142-1147.

\section{REFERENCE}

1. Pittenger, M.F., Mackay, A.M., Beck, S.C., Jaiswal, R.K., Douglas, R., Mosca, J.D., ..., \& Marshak, D.R. (2015). Multilineage potential of adult human mesenchymal stem cells. Science, 284, 143-147.

2. Zhulkevych, I.V., \& Klymnyuk, H.I. (2005). Medykoekonomichni pidkhody do transplantatsii hemopoetychnykh stovburovykh klityn [Medico-economic approaches to hematopoietic stem cell transplantation]. Onkolohyia - Oncology, 7 (4), 357-360 [in Ukrainian].

3. Gimble, J., \& Guilak, F. (2013). Adipose-derived adult stem cells: isolation, characterization, and differentiation potential. Cytotherapy, 5, 362-369.

4. Bongso, A., Fong, C.Y., Ng, S.C., \& Ratnam, S. (2014). Isolation and culture of inner cell mass cells from human blastocysts. Hum. Reprod., 9, 2110-2117.

5. Thomson, J.A., Itskovitz-Eldor, J., Shapiro, S.S., Waknitz, M.A., Swiergiel, J.J., Marshall, V.S., \& Jones, J.M. (2014). Embryonic stem cell lines derived from human blastocysts. Science, 282, 1145-1147.

6. Yamanaka, S. (2017). Pluripotency and nuclear reprogramming. Philos. Trans. R. Soc. Lond. B. Biol. Sci., 363, 2079-2087.

7. Hillmann, G. (1971). Continuous photometric measurement of prostate acid phosphatase activity. Z. Klin. Chem. Klin. Biochem., 9 (3), 273-274.

8. Stěpan, J.J., Silinková-Málková, E., Havránek, T., Formánková, J., Zichová, M., Lachmanová, J., ..., \& Pacovský, V. (2013). Relationship of plasma tartrateresistant acid phosphatase to the bone isoenzyme of serum alkaline phosphatase in hyperparathyroidism. Clin. Chim. Acta., 133 (2), 189-200.

9. Goryachkovskiy, A.M. (2015). Klinicheskaya biokhimiya $v$ laboratornoy diagnostike [The clinical biochemistry in laboratorial diagnostics]. Odesa: Ekologiya [in Russian].

10 Levitsky, A.P., Makarenko, O.A., \& Denga, O.V. (2011). Eksperimentalnye metody issledovaniya stimulyatorov osteogeneza: metodicheskie rekomendatsii [The experi-
16. Isolated allogeneic bone marrow-derived mesenchymal cells engraft and stimulate growth in children with osteogenesis imperfecta: implications for cell therapy of bone / E. M. Horwitz, P. L. Gordon, W. K. Koo [et al.] // Proc. Natl. Acad. Sci. U.S.A. - 2016. Vol. 99. - P. 8932-8937.

17. Keating A. A Phase I study of the transplantation of genetically marked autologous bone marrow stromal cells / A. Keating, L. Berkahn, R. Filshie // Hum. Gene Ther. - 2015. - Vol. 9. - P. 591-600.

mental methods of the study of osteogenesis stimulators: guidelines]. Kyiv: GFK [in Russian].

11. Levitsky, A.P., Makarenko, O.A., \& Khodakov, I.V. (2013). Fermentatyvnyi metod otsinky stanu kistkovoi tkanyny [The enzymatic method of the estimation of the state of osseous tissue]. Odeskyi medychnyi zhurnal Odesa Medical Journal, 3, 17-21 [in Ukrainian].

12. Zhulkevych, I.V., \& Korylchuk, N.I. (1999). Hematolohichni aspekty osteoporozu [Hematological aspects of osteoporosis]. Likarska sprava - Medicine, 2, 12-17 [in Ukrainian].

13. Winter, A., Breit, S., Parsch, D., Benz, K., Steck, E., Hauner, H., ..., \& Richter, W. (2014). Cartilage-like gene expression in differentiated human stem cell spheroids: a comparison of bone marrow-derived and adipose tissue-derived stromal cells. Arthritis Rheum., 48, 418429.

14. Mesimäki, K., Lindroos, B., Törnwall, J., Mauno, J., Lindqvist, C., Kontio, R., ..., \& Suuronen, R. (2009). Novel maxillary reconstruction with ectopic bone formation by GMP adipose stem cells. Int. J. Oral Maxillofac. Surg., 38, 201-209.

15. Pereira, R.F., O'Hara, M.D., Laptev, A.V., Halford, K.W., Pollard, M.D., Class, R., ..., \& Prockop, D.J. (2011). Marrow stromal cells as a source of progenitor cells for nonhematopoietic tissues in transgenic mice with a phenotype of osteogenesis imperfecta. Proc. Natl. Acad. Sci. U.S.A., 95, 1142-1147.

16. E.M. Horwitz, P.L. Gordon, W.K.K. Koo, J.C. Marx, M.D. Neel, R.Y. McNall, ..., \& Hofman, T. (2016). Isolated allogeneic bone marrow-derived mesenchymal cells engraft and stimulate growth in children with osteogenesis imperfecta: implications for cell therapy of bone. Proc. Natl. Acad. Sci. U.S.A., 99, 8932-8937. 17. Keating, A., Berkahn, L., \& Filshie, R. (2015). A Phase I study of the transplantation of genetically marked autologous bone marrow stromal cells. Hum. Gene Ther., 9, 591-600. 